\title{
Analytical survey of scenario for permanent method of contraception
}

\author{
Vandana Agarwal ${ }^{1}$, Rekha Mehani ${ }^{2 *}$, Swati Jain ${ }^{3}$
}

\begin{abstract}
${ }^{1}$ Department of Obstetrics and Gynaecology, RKDFMCH RC Bhopal, Madhya Pradesh, India
${ }^{2}$ Department of Pharmacology, RKDFMCH RC Bhopal, Madhya Pradesh, India

${ }^{3}$ Department of Community Medicine, RKDFMCH RC Bhopal, Madhya Pradesh, India
\end{abstract}

Received: 26 November 2020

Accepted: 29 December 2020

\author{
*Correspondence: \\ Dr. Rekha Mehani, \\ E-mail: drrekhasanjay@gmail.com
}

Copyright: ( $)$ the author(s), publisher and licensee Medip Academy. This is an open-access article distributed under the terms of the Creative Commons Attribution Non-Commercial License, which permits unrestricted non-commercial use, distribution, and reproduction in any medium, provided the original work is properly cited.

\section{ABSTRACT}

Background: This study has analysed the average completed family size with relation to parity, average age of both partners accepting permanent contraception, the percentage of women who finished their family with only female children and comparison of practice observed in rural and urban population.

Methods: A retrospective analytical study was conducted at RKDF medical college and research centre Bhopal M.P. from 1 January 2017 to 31 August 2020 (3 Years 7 months) on 286 patients. Data of the patients who had undergone tubal ligation after normal vaginal delivery, caesarean section, with medical termination of pregnancy and interval tubectomy was collected at RKDF medical college and research centre Bhopal M.P.

Results: Parity wise maximum number of cases completed their family with two issues i.e. (51\%). Permanent sterilisation was done in even one issue in $(0.6 \%)$ minimum number of cases were observed in 9 issues $(0.34 \%)$. Rural versus urban distribution was 25 and $75 \%$ respectively. Maximum age observed was 47 years of husband and 42 years of wife.

Conclusions: For the desire of male child, number of female children increased thereby increasing the family size.

Keywords: Parity, Family size, Male child, Permanent contraception

\section{INTRODUCTION}

Historically, in India to promote the family planning program government focused heavily on the promotion of permanent methods in response to the need for controlling rapid population growth and widespread poverty. ${ }^{1-4}$ Then in late 1970 s, the program shifted its focus towards female sterilization which thereafter continued to dominate the Indian family planning program. In order to promote female sterilization health workers vigorously promoted to fulfil their targets and often misled women about other method choices. ${ }^{5}$ Son preference and sterilization use among young married women was a frequent observation in slums of Bhopal city, India

During research it was a significant observation that women's reproductive behaviour is strongly influenced by their normative environment. One such norm observed strongly in India was son preference which interacts with family size. This norm also had a great impact on a desired ratio of sons to daughters to influence what is considered to be an 'ideal' family which, in turn, plays an important role in shaping reproductive behaviours. ${ }^{6-8}$ In India over the last four decades Women's reproductive choices have also been shaped by India's family planning policy, implemented in the early 1950s. In particular, the family planning program's historical focus on female sterilisation as a form of birth control.

This paper addresses how the son preference norm and family planning policy together influenced in the decisions for family size, composition in Bhopal, India. Specifically, we analysed the extent to which son preference played a role in women sterilisation, compared to other factors that could influence this decision, such as education and the number of children. We also examined 
how the effect of son preference on the decision to stop childbearing interacts with an emerging preference for smaller families. However, analysis also revealed few families where sterilisation process was implemented after only one or two females.

\section{METHODS}

A retrospective analytical study was conducted at RKDF medical college and research centre Bhopal M.P. From 1 January 2017 to 31 August 2020 on 286 patients. Ethical clearance was done. Data of the patients who had undergone tubal ligation after normal vaginal delivery, caesarean section, with medical termination of pregnancy and interval tubectomy (TT) was collected. The number of cases from rural and urban population were considered. Age of husband and wife were recorded individually. Parity status of individual female was taken in analysis. Individual count of male and female off springs of each couple was recorded.

\section{Age of the couple}

Husband's age: Minimum 25 years, maximum 47 years. Wife's age: Minimum 20 years, maximum 42 years.

\section{RESULTS}

Maximum age of wife at which female sterilisation was done were observed in the 25-26 years age grp (21\%) and 29-30 years $(21 \%)$. With advanced age the percentage of sterilisation decreased. Regarding the age of male partner maximum case of female sterilisation were observed in the age group 29-30 years $(22 \%)$ cases were seen in the age grp of 25-26 years also. In the age group of 47 years $(0.3 \%)$ cases were observed in the above research analysis (Table 1).

Maximum female sterilisation was observed after two issues (51\%). Surprisingly in 2 cases $(0.6 \%)$ female sterilisation was observed after a single issue. $0.34 \%$ case were observed after 7 and 9 issues respectively. In the above study the ratio of urban versus rural population was 75 and $25 \%$ respectively. Sterilisation was predominated in urban population. In the rural population few cases of female sterilisation were observed after 7 and 9 issues also (Table 2).

Table 1: Age distribution of husband and wife.

\begin{tabular}{|llllll|}
$\begin{array}{l}\text { Husband's } \\
\text { age (year) }\end{array}$ & No. & $\%$ & $\begin{array}{l}\text { Wife's } \\
\text { age } \\
\text { (year) }\end{array}$ & No. & $\%$ \\
\hline $\mathbf{2 0 - 2 2}$ & 0 & - & $20-22$ & 8 & 1 \\
\hline $\mathbf{2 3 - 2 4}$ & 0 & - & $23-24$ & 22 & 7 \\
\hline $\mathbf{2 5 - 2 6}$ & 12 & 4 & $25-26$ & 61 & 21 \\
\hline $\mathbf{2 7 - 2 8}$ & 11 & 3 & $27-28$ & 45 & 15 \\
\hline $\mathbf{2 9 - 3 0}$ & 62 & 22 & $29-30$ & 61 & 21 \\
\hline $\mathbf{3 1 - 3 2}$ & 40 & 14 & $31-32$ & 28 & 9 \\
\hline $\mathbf{3 3 - 3 4}$ & 36 & 13 & $33-34$ & 12 & 4 \\
\hline $\mathbf{3 7 - 3 8}$ & 25 & 9 & $37-42$ & 10 & 3 \\
\hline $\mathbf{3 9 - 4 0}$ & 23 & 8 & & & \\
\hline $\mathbf{4 1 - 4 2}$ & 7 & 2 & & & \\
\hline $\mathbf{4 3 - 4 4}$ & 2 & 0.6 & & & \\
\hline $\mathbf{4 5 - 4 6}$ & 1 & 0.3 & & & \\
\hline $\mathbf{4 7}$ & 1 & 0.3 & & & \\
\hline
\end{tabular}

Table 2: Urban/rural distribution.

\begin{tabular}{|llll|}
\hline Issues & Urban & Rural & Sterilisation \\
\hline $\mathbf{1}$ issue & $2(0.6)$ & - & $2(1)$ \\
\hline $\mathbf{2}$ issues & $146(51)$ & $17(49)$ & $111(52)$ \\
\hline $\mathbf{3}$ issues & $91(32)$ & $35(24)$ & $74(34)$ \\
\hline $\mathbf{4}$ issues & $35(12)$ & $11(16)$ & $24(11)$ \\
\hline $\mathbf{5}$ issues & $6(2)$ & $4(5.7)$ & $2(1)$ \\
\hline $\mathbf{6}$ issues & $4(1)$ & $2(3)$ & $2(1)$ \\
\hline $\mathbf{7}$ issues & $1(0.34)$ & $1(1.4)$ & - \\
\hline $\mathbf{9}$ issues & $1(0.34)$ & $1(1.4)$ & - \\
\hline
\end{tabular}

Table 3: Counts of male and female offspring.

\begin{tabular}{|c|c|c|c|c|c|c|c|}
\hline $\begin{array}{l}\text { No. of } \\
\text { issues }\end{array}$ & $\begin{array}{l}\text { No. of cases } \\
(\%)\end{array}$ & $\begin{array}{l}\text { All males } \\
(\%)\end{array}$ & $\begin{array}{l}\text { All females } \\
(\%)\end{array}$ & 1 male & 2 males & 3 males & 4 males \\
\hline 1 issue & $2(0.6)$ & 1 & 1 & - & - & - & - \\
\hline 2 issue & $146(51)$ & $\begin{array}{l}\text { All two issues } \\
37(25)\end{array}$ & $\begin{array}{l}\text { All two } \\
9(6)\end{array}$ & $100(68)$ & - & - & - \\
\hline 3 issue & $91(32)$ & $\begin{array}{l}\text { All three issues } \\
7(8)\end{array}$ & $\begin{array}{l}\text { All three } \\
14(15)\end{array}$ & 35 & 35 & - & - \\
\hline 4 issue & $35(12)$ & 0 & 2 & 15 & 15 & 2 & 1 \\
\hline 5 issue & $6(2)$ & 0 & 0 & 3 & 2 & 0 & 1 \\
\hline 6 issue & $4(1)$ & 0 & $\begin{array}{l}5 \text { females } \\
(2 \text { cases })\end{array}$ & 2 & 2 & - & - \\
\hline 7 issue & $1(0.34)$ & 0 & $\begin{array}{l}5 \text { females } \\
(2 \text { cases })\end{array}$ & - & - & - & - \\
\hline 9 issue & $1(0.34)$ & 0 & $\begin{array}{l}9 \text { females } \\
\text { (1 case) }\end{array}$ & - & - & - & - \\
\hline
\end{tabular}


Maximum number of cases completed their family with 2 issues $(51 \%)$, with 1 male and 1 female $(68 \%)$ in the family and with 2 females $(6 \%)$ in the family. In three issues family $(32 \%) 15 \%$ cases were observed where all were three females. Families with 4 issues (12\%) 2 families were observed where all four were females.

For the desire of a male child parity increased up to 3 issues in $32 \%$. Up to 4 issues in $12 \%$. and more than 5 issues in $4 \%$. It was observed that for desire of a male issue size of family increased up to 6, 7 and 9 issues also (Table 3).

\section{DISCUSSION}

In the above analytical scenario, it is very surprising that in India sterilisation is not that effective method to control population or to limit family size. Sterilisation was predominantly used as a method family planning programme, mainly by those who had completed their family size. The acceptors were mainly older and of relatively high parities, lowering the effectiveness of the programme on total fertility rates and suggesting that the focus should be on younger women with fewer children to make it more effective. ${ }^{9}$

Preference of a male issue and the use of sterilisation as a permanent method.

Including India, it has been found during studies in several countries that families without male issues are less likely to use permanent method of contraception than the families with male issues. ${ }^{10-13}$ Most of the above studies, however, focus exclusively on the effect of the male issue preference and/or gender composition on the usage of permanent methods of contraception.

\section{Limitations}

Only one centre's patients could be included in our study. As compared to urban population rural population patients' number was less in the study.

\section{CONCLUSION}

For the desire of male child, number of female children increased thereby increasing the family size.

Funding: No funding sources

Conflict of interest: None declared

Ethical approval: The study was approved by the Institutional Ethics Committee

\section{REFERENCES}

1. Bairagi R. Effects of sex preference on contraceptive use, abortion and fertility in Matlab, Bangladesh. Int Family Planning Perspect. 2001;27(3):137-43.

2. Barua A, Kurz K. Reproductive health-seeking by married adolescent girls in Maharashtra, India. Reproduct Health Matters. 2001;9(17):53-62.

3. Barua A, Pande R, MacQuarrie K, Walia S. Caring men? Husbands' involvement in maternal care of young wives. Economic Political Weekly. 2004;39(52):5661-8.

4. Bhat PN, Zavier MA. Fertility decline and gender bias in northern India. Demography. 2003;40(4):63757.

5. Pande R. Selective gender differences in childhood nutrition and immunization in rural India: The role of siblings. Demography. 2003;40(3):395-418.

6. Retherford RD, Roy TK. National family health survey subject reports, nr. 21. Mumbai, India: International Institute for Population Sciences (IIPS). Factors affecting sex-selective abortion in India and 17 major states. 2003;78.

7. Dharmalingam A. The social context of family size preferences and fertility behaviour in a south Indian village. Genus. 1996;52(1-2):83-103.

8. Clark S. Son preference and sex composition of children: $\quad$ Evidence from India. Demography. 2000;37(1):95-108.

9. Donaldson P. The elimination of contraceptive acceptor targets and the evolution of population policy in India. Population Studies. 2002;56(1):97110.

10. Hussain R, Fikree FF, Berendes HW. The role of son preference in reproductive behaviour in Pakistan. Bull WHO. 2000;78(3):379-88.

11. Yount KM, Langsten R, Hill K. The effect of gender preference on contraceptive use and fertility in rural Egypt. Studies Family Planning. 2000;31(4):290300.

12. Leone T, Matthews Z, Dalla Zuanna G. Impact and determinants of sex preference in Nepal. Int Family Planning Perspect. 2003;29(2):69-75.

13. Anuja J, Mishra V, Arnold F. The Effect of Family Size and Composition on Fertility Desires, Contraceptive Adoption, and Method Choice in South Asia. DHS Working Papers No. 40. Calverton, Maryland, USA: Macro International. 2008;1-26.

Cite this article as: Agarwal V, Mehani R, Jain S. Analytical survey of scenario for permanent method of contraception. Int J Reprod Contracept Obstet Gynecol 2021;10:588-90. 